\title{
Trematodiasis occurrence in cattle along the Progo River, Yogyakarta, Indonesia
}

\author{
Korbinianus Feribertus Rinca, Joko Prastowo, Dwi Priyo Widodo, and Yudhi Ratna Nugraheni
}

Department of Parasitology, Faculty of Veterinary Medicine, Universitas Gadjah Mada, Yogyakarta, Indonesia.

Corresponding author: Yudhi Ratna Nugraheni, e-mail: yudhi.ratna.n@mail.ugm.ac.id

Co-authors: KFR: Korbin.nikat@gmail.com,JP: joko2465@ugm.ac.id, DPW: priyo@ugm.ac.id Received: 04-11-2018, Accepted: 05-03-2019, Published online: 22-04-2019

doi: 10.14202/vetworld.2019.593-597 How to cite this article: Rinca KF, Prastowo J, Widodo DP, Nugraheni YR (2019) Trematodiasis occurrence in cattle along the Progo River, Yogyakarta, Indonesia, Veterinary World, 12(4): 593-597.

\begin{abstract}
Aim: This study aimed to measure the occurrence of trematodiasis in cattle along the Progo River, a district of Yogyakarta, Indonesia. The findings help to establish the magnitude of the disease and encourage prevention and treatment of this condition.
\end{abstract}

Materials and Methods: Trematode eggs were extracted from 100 fecal samples collected from cattle. The eggs were examined using the sedimentation technique, and the method of Parfitt and Banks was used to differentiate Paramphistomum spp. eggs from Fasciola spp. eggs.

Results: The infection rate of trematode parasites was $50 \%$. Cattle experienced multiple infections of both Paramphistomum spp. and Fasciola spp., as well as single infections of one species or the other. All breeds were vulnerable to infections of both trematode species, although different cattle breeds, including Peranakan Ongole crossbreeds, Simmental crossbreeds, and Limousin crossbreeds, showed differences in infection rate. The highest rate of infection with Paramphistomum spp. (15.78\%) occurred in the Simmental crossbreeds. The highest rate of infection (31.57\%) with Fasciola spp. was in the Peranakan Ongole crossbreeds. Multiple infections of both Paramphistomum spp. and Fasciola spp. were highest in Simmental crossbreed cattle (28.97\%).

Conclusion: The high infection rates of trematode parasites found in fecal samples, particularly of Fasciola spp., indicate that the cattle along the Progo River in Indonesia experience a high rate of trematodiasis disease.

Keywords: cattle, Fasciola spp., identification, Indonesia, Paramphistomum spp., Yogyakarta.

\section{Introduction}

Commercial production of cattle in Indonesia faces various problems that require immediate attention. A major problem is disease, which directly affects animal health and reduces profits for cattle owners. Another increasing problem is economic losses at feedlots due to a reduction in the feed-conversion ratio and low distribution of body weight [1].

Of many factors that affect the economic value of cattle, an important one is infectious disease caused by parasites. Parasitic infections in animals can inhibit health, reduce growth, cause low birth weight, cause reproductive problems, and reduce the profitability of carcasses. Parasite disease is the main cause of economic losses in world livestock [2-4]. Economic losses due to parasites result from a reduction in the livestock population, reduced milk productivity, and reduced quantity of meat, as well as damage to some animal parts, such as the liver, that are infested with parasites and must be discarded [5]. Paramphistomum spp. and

Copyright: Rinca, et al. Open Access. This article is distributed under the terms of the Creative Commons Attribution 4.0 International License (http://creativecommons.org/licenses/by/4.0/), which permits unrestricted use, distribution, and reproduction in any medium, provided you give appropriate credit to the original author(s) and the source, provide a link to the Creative Commons license, and indicate if changes were made. The Creative Commons Public Domain Dedication waiver (http://creativecommons.org/ publicdomain/zero/1.0/) applies to the data made available in this article, unless otherwise stated.
Fasciola spp. are the most common parasites that infect cattle in Indonesia, including in research locations, and no official measures are in place to eliminate trematodes from cattle in Indonesia. Trematodes and other parasites are responsible for heavy losses to livestock in Indonesia, hindering progress toward the government's goal of self-sufficiency. It is necessary to research the trematodiasis incidence in Indonesia so that the data can form the basis for the local government to implement prevention and control policies regarding trematodiasis.

As noted, Paramphistomum spp. and Fasciola spp. are the main parasitic species causing disease in cattle in Indonesia [6,7]. Paramphistomiasis has appeared as a gastrointestinal disease in pets, causing high economic losses [8]. Fasciolosis in animals has a direct economic impact that is most generally experienced by breeders or owners in livestock sectors, due to the rejection of diseased animal parts such as livers, a reduction in animal productivity, a reduction in growth rate, and low calf birth weight for offspring of infected mothers [9]. The worldwide economic loss as a result of parasite infection, including fasciolosis in ruminants, is estimated to be US\$3 billion/year [10]. No research has been conducted on trematodiasis in cattle reared along the Progo River, a special district of Yogyakarta, Indonesia, so this location was chosen for the present research.

This study aimed to measure trematodiasis in cattle along the Progo River. The data were intended 
to establish the magnitude of the disease and encourage preventive and treatment efforts.

\section{Materials and Methods}

Ethical approval

All procedures performed in this study were in accordance with the ethical standards of the Faculty of Veterinary Medicine, Universitas Gadjah Mada. No specific permissions were required. Samples were collected following standard procedures, without any harm to the animals.

\section{Sampling}

A total of 100 fecal samples were collected from April 2018 to October 2018 from cattle reared along the Progo River. Feces were collected directly from cattle rectums. Samples were placed in plastic bags and brought to the Parasitological Laboratory at the Faculty of Veterinary Medicine, Gadjah Mada University, in a cooler. Fecal samples were then stored in a refrigerator at $4^{\circ} \mathrm{C}$ until further examination.

\section{Parfitt-Banks method}

This method was used to determine the number of trematode eggs in cattle feces from 2-g fecal samples. Feces were placed in a mortar to which $20 \mathrm{~mL}$ of water was added. The mixture was filtered and included in the tube up to a height of $2 \mathrm{~cm}$ on the tube nozzle. The solution was allowed to stand for $15 \mathrm{~min}$ to form a precipitate. The clear liquid was removed and a precipitate $1 \mathrm{~cm}$ in height remained. Water was added to the remaining mixture in the tube up to a height of $2 \mathrm{~cm}$ on the tube nozzle, and then it was stirred and allowed to remain for at least 15 minutes, until a precipitate formed. The clear liquid was removed, up to three drops of $10 \% \mathrm{NaOH}$ were added, and water was added to reach a height of $2 \mathrm{~cm}$ on the tube nozzle. The solution was made homogeneous by stirring and left for $15 \mathrm{~min}$ to form a precipitate. The clear liquid was removed; two drops of methylene blue were added, and the mixture was allowed to stand for some minutes. The solution of feces and methylene blue was poured into a petri dish for examination under the binocular microscope with a $4 \times$ magnification lens. If necessary, several milliliters of water were added to facilitate observation. Worm eggs were observed and documented. They were discriminated on the basis of color; Paramphistomum spp. appeared transparent and deep blue, while Fasciola spp. eggs were golden yellow in color [11]. Identification of trematode eggs was based on the literature [12].

\section{Results}

The examination of feces following the method of Parfitt and Banks indicated a high rate of infection with trematode parasites among the 100 cattle sampled. The rate of infection of Paramphistomum spp. solely was $47 \%$ and that of Fasciola spp. solely was $48 \%$, as shown in Table 1.

Cattle reared traditionally by the local people are the results of artificial insemination, which has produced some new breeds, such as crossbreeds between Ongole cattle and the local cattle, creating the Peranakan Ongole (PO) crossbreed; the Simmental crossbreed; and the Limousine crossbreed. Multiple infections of both Paramphistomum spp. and Fasciola spp. were found at a rate of $28.95 \%$ in Simmental crossbreeds, $23.25 \%$ in Limousine crossbreeds, and $21.05 \%$ in PO crossbreeds. Single infections of Paramphistomum spp. occurred at a rate of $15.79 \%$ in Simmental crossbreeds, $10.53 \%$ in PO crossbreeds, and $9.30 \%$ in Limousine crossbreeds. Single infections of Fasciola spp. occurred at a rate of $31.58 \%$ in PO crossbreeds, $7.89 \%$ in Simmental crossbreeds, and $4.65 \%$ in Limousine crossbreeds, as shown in Table 2.

\section{Discussion}

The rate of trematodiasis in cattle in the Progo river flow zone reaches $50 \%$. This rate is higher than the rate of trematodiasis reported in Central Sulawesi, Indonesia (38.31\%) [13], and the rate of infection with multiple trematode species is higher than in Malaysia $(10 \%)$ [14]. These high rates of infection with both species might be caused by ineffective treatment, the immune response of different host species, cattle rearing management, differences in animal species and breeds, differences in the parasite measurement technique, differences in geography or climate, variations in ecological conditions, and the presence of intermediary hosts. At the study site, Paramphistomum spp. and Fasciola spp. were found living in watery, swampy areas that are suitable for the development and reproduction of the intermediary host, resulting in high prevalence [15].

The rate of Paramphistomum spp. infection in cattle in the Progo river flow zone was $47 \%$, higher than in a previous study [16]. The rate of trematodiasis was $4 \%$ in Central Java, Indonesia; $12.1 \%$ in Aljazair [17]; $12 \%$ in northern Portugal and northwest Spain [18]; 18.8\% in Galicia (Spain) [19]; 7\% in northwest Uruguay and northwest Spain [20]; and $18.8 \%$ in Ethiopia [21]. The infection rate in the present study was higher than in a study conducted in northwest Ethiopia, where it was $45.85 \%$ [22]. These differences may be affected by factors such as differences in sample size, diagnostic technique, climate, ecology, and livestock management system [23].

Table-1: Results of sedimentation test to determine the presence of Paramphistomum spp. and Fasciola spp. eggs in cattle feces.

\begin{tabular}{lccc}
\hline Type of egg & $\begin{array}{c}\text { Number of samples } \\
\text { assessed }\end{array}$ & $\begin{array}{c}\text { Number of samples that } \\
\text { contained trematode eggs }\end{array}$ & $\begin{array}{r}\text { Percentage of } \\
\text { infection (\%) }\end{array}$ \\
\hline Paramphistomum spp. & 100 & 47 & 47 \\
Fasciola spp. & 100 & 48 & 48 \\
\hline
\end{tabular}




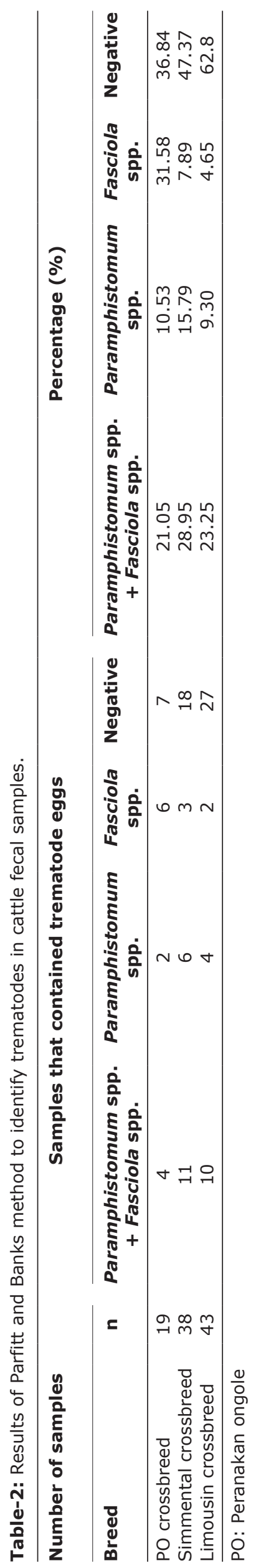

The rate of Fasciola spp. infection reached $48 \%$, higher than in previous studies that found rates of $3.28 \%$ in Iran [24] and $22.17 \%$ in Bangladesh [25]. However, it was lower than reported by Ashraf et al., indicating that Fasciola spp. infection in cattle in tropical areas ranged from $30 \%$ to $90 \%$ [26]. Other studies reported Fasciola spp. infection rates of $36 \%$ in Sobangan Bali [27], 33.33\% in Egypt [28], and 18\% in Australia [29]. The difference in incidence between areas might be caused by differences in livestock rearing method, number of total samples, cattle composition, biological potentials of intermediary host and host, climate and topography of sampling location, metacercariae resistance in the environment, and diagnostic technique [30,31].

Infection rates of Paramphistomum spp. and Fasciola spp. of various cattle breeds in the present study were highly affected by rearing management. A previous report from Japan [32] showed that the rate of fasciolosis was higher in cattle breeds originating from Japan than in Friesian and Jersey breeds, due to management factors. Friesian breeds were not pastured on grassland, whereas Japanese breeds were pastured on natural grassland wet fields and were able to feed on rice straw, resulting in a higher rate of fasciolosis. Feeding rice straw also affected the rate of infection of Paramphistomum spp. The metacercaria on rice stalks are generally distributed along the bottom third of the rice stalk, so it is recommended to provide only the top half of the rice straw to cattle. In addition, using a grass drying method helped to prevent parasitic infection because exposure to direct sunlight for 2-3 days killed the metacercaria [33].

Malnutrition in animals also increases their vulnerability to parasitic infections. Poor animal health also reduced cattle's resistance to infection challenges. Infection with Fasciola spp. was higher in cattle that had poor body condition scores (BCS). Many studies have indicated that there is a positive correlation between a reduction in cattle body weight and fasciolosis. The prevalence of fasciolosis was $85.9 \%$ for those in poor condition, $55.1 \%$ for those in medium weight, and $34.5 \%$ in those with good body weight [34]. A previous study by Jaja et al. [35] reported a significant correlation between BCS and infection intensity, suggesting that poor body condition might be a direct result of fasciolosis pathogenesis. Considering the important role of homeostasis in the liver and all metabolisms of animals, loss of BCS in infected cattle could be a result of Fasciola infection and might be correlated with metabolic disorders [36].

\section{Conclusion}

The data from the present study indicated that the infection rate with multiple trematode parasites was highest in PO crossbreed cattle, whereas the percentage of Paramphistomum spp. infection alone was highest in the Simmental crossbreeds. These results should be applied to the development of a management 
plan to reduce the incidence of trematodiasis in this region.

\section{Authors' Contributions}

DPW, YRN, DPW, and JP designed the study. KFR and YRN conducted the field survey, collected samples, and examined them in the laboratory. All authors drafted and revised the manuscript. All authors read and approved the final manuscript.

\section{Acknowledgments}

The authors are thankful to the Veterinary Science Faculty Postgraduate Study Program at the Faculty of Veterinary Medicine, Gadjah Mada University, as a research funder with grant number 1583/J01.1.22/ HK4/2018.

\section{Competing Interests} interests.

The authors declare that they have no competing

\section{Publisher's Note}

Veterinary World remains neutral with regard to jurisdictional claims in published institutional affiliations.

\section{References}

1. Mudani, M. (2011) The level of liver flukes infection and its relation to the economic loss of cattle at the abattoir of Banyumas ex-Resident. Agripet, 11(1): 45-50.

2. Grisi, L., Leite, R.C., de Martins, J.R.S. and de Barros, A.T.M. (2014) Reassessment of the potential economic impact of cattle parasites in Brazil. Rev. Bras. Parasitol. Vet., 23(2): 150-156.

3. Assefa, A. and Tesfay, H. (2013) Major causes of organ condemnation and economic loss in cattle slaughtered at Adigrat municipal abattoir, Northern Ethiopia. Vet. World, 6(10): 734-738.

4. Borji, H., Azizzadeh, M. and Kamelli, M. (2012) A retrospective study of abattoir condemnation due to parasitic infections: Economic importance in Ahwaz, Southwestern Iran. J. Parasitol., 98(5): 954-957.

5. Rodríguez-Vivas, R.I., Grisi, L., De León, A.A.P., Villela, H.S., De Jesús Torres-Acosta, J.F., Sánchez, H.F., Salas, D.R., Cruz, R.R., Saldierna, F. and Carrasco, D.G. (2017) Potential economic assessment for cattle parasite in Mexico. Rev. Mex. Cien. Pecu., 8(1): 61-74.

6. Handayani, P., Santosa, P.E. and Siswanto, S. (2015) Infestation rate of the digestive fluke on Bali cattle in Sukoharjo sub-district Pringsewu district Lampung Province. J. Ilmiah Peternakan Terpadu, 3(3): 127-133.

7. Hambal, M., Sayuti, A. and Dermawan, A. (2013) Susceptibility of bovine and Bubalis spp. on Fasciola gigantica in Lhoong sub-district Aceh Besar. Med. Vet., 7(1): 49-53.

8. Ozdal, N., Gul, A., Ilhan, F. and Deger, S. (2010) Prevalence of Paramphistomum infection in cattle and sheep in Van Province, Turkey. Helminthologia, 47(1): 20-24.

9. Usip, L.P., Ibanga, E.S., Edoho, H.J., Amadi, E.C. and Utah, E. (2014) Prevalence of fasciolosis and the economic loss of condemned liver due to Fasciola infection in cattle slaughtered at three abattoirs in Eket Urban, Akwa Ibom State of Nigeria. Glob. Adv. Res. J. Food. Sci Technol., 3(2): 54-75.

10. Elelu, N. and Eisler, N.C. (2018) A review of bovine fasciolosis and other trematode infections in Nigeria. J. Helminthol., 92(2): 128-141.
11. Rozi, F., Handoko, J. and Febriyanti, R. (2015) Infestation of luke worm (Fasciola spp.) and stomach worm (Paramphistomum spp.) on adult Bali cattle in Tenayan Raya Pekanbaru municipality. Indones. J. Vet. Sci., 33(1): 8-15.

12. Thienpont, D., Rochette, F. and Vanparijs, O.F.J. (1985) Diagnosis of Helminthiasis: Coprological Examination. $2^{\text {th }}$ ed. Janssen Research Foundation, Belgium. p79.

13. Budiono, N.G., Satrija, F., Ridwan, Y., Nur, D. and Hasmawati, H. (2018) Trematodoses in cattle and buffalo around schistosomiasis endemic areas in Central Sulawesi Province of Indonesia. J. Ilmu Pertanian Indones., 23(2): 112-126.

14. Khadijah, S., Ariff, Z., Nurlaili, M.R., Sakiinah, A., Izzudin, A.H., Mursyidah, A.K., Rita, N. and Aida, H.N. (2017) Fasciola and Paramphistomum infection in large ruminants. Int. J. Agron. Agri. Res., 10(6): 19-26.

15. Fromsa, A., Meharenet, B. and Mekibib, B. (2011) Major trematode infections of cattle slaughtered at Jimma municipality abattoir and occurrence of the intermediate hosts in selected water bodies of the zona. J. Anim. Vet. Adv., 10(12): 1592-1597.

16. Hamid, P.H., Kristianingrum, Y.P., Prastowo, J. and Da Silva, L.M.R. (2017) Gastrointestinal parasites of cattle in Central Java. Am. J. Anim. Vet. Sci., 11(3): 119-124.

17. Titi, A., Mekroud, A., Sedraoui, S., Vignoles, P. and Rondelaud, D. (2010) prevalence and intensity of Paramphistomum daubneyi infections in cattle from NorthEastern Algeria. J. Helminthol., 84(2): 177-181.

18. Arias, M., Lomba, C., Dacal, V., Vázquez, L., Pedreira, J., Francisco, I., Piñeiro, P., Cazapal-Monteiro, C., Suárez, J.L., Díez-Baños, P., Morrondo, P., Sánchez-Andrade, R. and Paz-Silva, A. (2011) Prevalence of mixed trematode infections in an abattoir receiving cattle from Northern Portugal and North-West Spain. Vet. Rec., 168(15): 408.

19. González-Warleta, M., Lladosa, S., Castro-Hermida, J.A., Martínez-Ibeas, A.M., Conesa, D., Muñoz, F., LópezQuílez, A., Manga-González, Y. and Mezo, M. (2013) Bovine paramphistomosis in Galicia (Spain): Prevalence, intensity, etiology and geospatial distribution of the infection. Vet. Parasitol., 191(3-4): 252-263.

20. Sanchís, J., Sánchez-Andrade, R., Macchi, M.I., Piñeiro, P., Suárez, J.L., Cazapal-Monteiro, C., Maldini, G., Venzal, J.M., Paz-Silva, A. and Arias, M.S. (2013) Infection by paramphistomidae trematodes in cattle from two agricultural regions in NW Uruguay and NW Spain. Vet. Parasitol., 191(1-2): 165-171.

21. Ibrahim, N., Tefera, M., Bekele, M. and Alemu, S. (2014) Prevalence of gastrointestinal parasites of small ruminants in and around Jimma town, Western Ethiopia. Acta Parasitol. Glob., 5(1): 12-18.

22. Yeneneh, A., Kebede, H., Fentahun, T. and Chanie, M. (2012) Prevalence of cattle flukes infection at Andassa livestock research center in North-West of Ethiopia. Vet. Res. Forum, 3(2): 85-89.

23. Khedri, J., Radfar, M.H., Borji, H. and Mirzaei, M. (2015) Prevalence and intensity of Paramphistomum spp. In cattle from South-Eastern Iran. Iran. J. Parasitol., 10(2): 268-272.

24. Khoramian, H., Arbabi, M., Asqoi, M.M., Delavari, M., Hooshyar, H. and Asgari, M. (2014) Prevalence of ruminants fasciolosis and their economic effects in Kashan, center of Iran. Pac. J. Trop. Biomed., 4(11): 918-922.

25. Islam, K.M., Islam, M.S., Adhikary, G.N., Hossain, K.M.M., Rauf, S.M.A. and Rahman, M. (2016) Epidemiological studies of fasciolosis (Fasciola gigantica infection) in cattle. J. Adv. Parasitol., 3(1): 10-13.

26. Ashraf, K., Bargues, M.D., O’Neill, S. and Mas-Coma, S. (2014) Fasciolosis: A worldwide parasitic disease of importance in travel medicine. Travel Med. Infect. Dis., 12(6): 636-649.

27. Putra, D.R., Nyoman, A.S. and Ida, B.M.O. (2014) The prevalence of trematodes in Bali cattle breeders reared in the Sobangan village, Mengwi district, Badung counties. 
Indones. Med. Vet., 3(5): 394-402.

28. Elshraway, N.T. and Mahmoud, W.G. (2017) Prevalence of fasciolosis (liver flukes) infection in cattle and buffaloes slaughtered at the municipal abattoir of El-Kharga, Egypt. Vet. World, 10(8): 914-917.

29. Elliott, T.P., Kelley, J.M., Rawlin, G. and Spithill, T.W. (2015) High prevalence of fasciolosis and evaluation of drug efficacy against Fasciola hepatica in dairy cattle in the Maffra and Bairnsdale districts of Gippsland, Victoria, Australia. Vet. Parasitol., 209(1-2): 117-124.

30. Choudhary, V., Garg, S., Chourasia, R., Hasnani, J., Patel, P., Shah, T.M., Bhatt, V.D., Mohapatra, A., Blake, D.P. and Joshi, C.G. (2015) Transcriptome analysis of the adult rumen fluke Paramphistomum cervi following next generation sequencing. Gene, 570(1): 64-70.

31. Melaku, S. and Addis, M. (2012) Prevalence and intensity of Paramphistomum in ruminants slaughtered at Debre Zeit industrial abattoir, Ethiopia. Glob. Vet., 8(3): 315-319.

32. Kato, M., Murakami, Y., Shimizu, M., Yamamoto, H.,
Yonemoto, Y., Ishii, K. and Kira, S. (2005) Survey of cattle fasciolosis in Tsuyama abattoir. Environ. Health Prev. Med., 10(3): 162-165.

33. Martindah, E., Widjajanti, S., Estuningsih, S.E. and Suhardono, D. (2005) Improvement of public awareness of fasciolosis as zoonosis disease. Wartazoa, 15(3): 143-154.

34. Demssie, A., Birku, F., Biadglign, A., Misganaw, M., Besir, M. and Addis, M. (2012) An abattoir survey on the prevalence and monetary loss of fasciolosis in cattle in Jimma town. Adv. Biol. Res. (Rennes), 8(4): 381-385.

35. Jaja, I.F., Mushonga, B., Greenc, E. and Muchenje, V. (2017) Seasonal prevalence, body condition score and risk factors of bovine fasciolosis in South Africa. Vet. Anim. Sci., 4(2017): 1-7.

36. Alvares, R.C., Ansell, B.R.E., Gasser, R.B., Young, N.D., Jex, A.R. and Scheerlinck, J.P.Y. (2015) Transcriptional analysis identifies key genes involved in metabolism, fibrosis/tissue repair and the immune response against Fasciola hepatica in sheep liver. Parasit. Vectors, 8(1): 124.

$* * * * * * * *$ 